\author{
Ана Курпиел (Полска) \\ Центар Вили Брант за германски и европски студии \\ Универзитет во Вроцлав \\ Е-маил: anna.kurpiel@uwr.edu.pl
}

\title{
ИДЕНТИТЕТ И ЗНАЕЊЕ НА МАКЕДОНСКИТЕ ДЕЦА БЕГАЛЦИ ВО СОЦИЈАЛИСТИЧКА ПОЛСКА: ГЕОПОЛИТИКИ НА ОБРАЗОВАНИЕТО
}

Апстракт: Од 1948 година, сѐ до раните 1950-ти години, Народна Република Полска прифатила околу 15 илјади бегалци од Граѓанската војна во Грција. Бегалците, поврзани со поразената страна на Грчката комунистичка војска, сочинувале хетерогена група од Грци, Македонци и Ароманци, вклучувајќи и возрасни и деца. Полска, како многу други источноевропски земји, ги засолнувала, како дел од солидарноста меѓу комунистичките партии. Сепак, до 1956 година антијугословенскиот дискурс имал доминантно влијание врз судбината на бегалците во Полска, условувајќи бегалците со грчко потекло да бидат фаворизирана група, а оние со македонско потекло да бидат третирани како соработници на Тито.

Трудот има за цел да го претстави македонскиот училиштен систем организиран во Полска за бегалците, вклучувајќи го и непознатиот случај со македонските учебници за децата на училиште подготвени и испечатени во Полска. Анализата на учебниците е ставена во поширока рамка на меѓународната политика на Источниот блок и Југославија, полско-македонските врски во 20 век, како и на социологијата и историјата на знаењето.

Клучни зборови: Македонци, бегалци од Граѓанската војна во Грција, социологија на знаењето, едукација, проучувања на мигранти, учебници.

\section{Вовед}

Предмет на оваа статија е пренесувањето на знаењето, како локално така и формално, на децата бегалци од Македонија, кои дошле во Полска за време и по Граѓанската војна во Грција. Поимите користени во текстот, како и истражувачките прашања, доаѓаат од полињата на антропологијата, историјата и социологијата на знаењето. Најважните аспекти се: формалните и неформалните начини на ширење на знаењето, моќта на знаењето, геополитиките 
на знаењето и, воопшто, знаењето на мигрантите во прогонство. Прашањето за формалното знаење е подобро разработено поради постоењето документирани извори за грижата и образовниот систем организиран од страна на Полјаците за децата бегалци. Интересниот случај наведен во вториот дел од статијата се однесува на учебниците по македонски јазик, граматика и култура, испечатени во Народна Република Полска на преминот од 1950-тите и 1960-тите години. Меѓу единаесетте книги што се достапни во Полската национална библиотека има книги, буквари, книги по македонска граматика, избори на македонска литература и една книга со македонски народни приказни. Сите се објавени од Полската државна издавачка күќа за учебници (Państwowe Zakłady Wydawnictw Szkolnych). Нивното создавање, како што ќе објаснам во следниот текст, било детерминирано со легитимирање на македонската борба за самоидентификација.

\section{Македонските бегалци во Полска}

Првите 1013 деца дошле со возови преку Романија во 1948 година. Во 1949 година уште 1000 деца пристигнале во Полска. „Сомничави, недоверливи и исплашени“ - така се опишани во еден извештај. Обучени полувоено, подготвени да избегаат на звукот на автомобил. Возраст: од 3 до 14 години (Danforth, Boeschoten 2012). Децата бегалци од Граѓанската војна во Грција (1946 - 1949 г.) опишани погоре биле првите што морале да ја напуштат разрушената земја. Поголемиот дел од нив биле родени во северната провинција на Грција - Егејска Македонија, регионот што бил под контрола на Комунистичката партија на Грција (КПГ) и нејзината Демократска армија. Комунистичките водачи одлучиле да ги преместат сите деца надвор од нивната територија за да ги заштитат (официјална причина), како и за да ги мобилизираат и нивните родители (неофицијална причина). Тие побарале од други „братски“ комунистички земји, во тоа време вклучувајќи ја и Југославија, да им дадат засолништа на децата. Сите влади одговориле позитивно. Пролетта 1948 година, околу 15000 деца, во придружба со млади жени, наречени на македонски мајки, и партизани, ја поминале планинската граница со Југославија и оттаму биле испратени со возови во некои од југословенските републики, во Чехословачка, Романија, Унгарија, Германската Демократска Република и во Полска (Danforth, Boeschoten 2012).

Една година подоцна, грчките комунисти биле поразени. Околу шеесет илјади бегалци (партизани и нивните семејства) биле принудени да ја напуштат Грција. Овојпат бегалците ја поминале грчко-албанската граница. Југославија од „брат“ станала непријател откако, по поделбата меѓу Тито и Сталин, грчките комунисти ја поддржале СССР. Возрасните бегалци стигнале до Полска и СССР 
по морски пат (Ташкент), а подоцна до другите земји - Германската Демократска Република (ГДР), Чехословачка, Романија, Унгарија. И покрај акцијата на меѓународниот Црвен крст за повторно обединување на семејствата, сите родители не успеале да се обединат со своите протерани деца.

Полска им дала засолниште на повеќе од 15000 бегалци: 7410 Македонци, 7357 Грци и 448 Ароманци (Słabig 2008: 314)․․ㅠовеќе од 3200 од нив биле деца на возраст до 18 години².

\section{Институционален систем за грижа и образование во Полска}

Децата што дошле во Полска на крајот од 1948 и во 1949 година биле сместени во таканаречените државни образовни центри, кои биле организирани за нив во живописните планински одморалишта во Лондек Здруј, Солице Здруј, Душњики Здруј и Меѓугорje (Lądek-Zdrój, Solice-Zdrój, Duszniki-Zdrój и Międzygórze)³. Центрите имале за цел „да обезбедат добри животни и здравствени услови на децата кои им биле доверени, како и физички, ментален и морален развој“ (Наковски 1987: 109). Центрите во секој град се состоеле од сиропиталиште, градинка, основно училиште, болница или превенториум. Центарот бил раководен од директор назначен од Министерството за образование, како и негов заменик и образовен совет. Вкупно 40 сиропиталишта биле создадени во центрите, секое со по околу 60 ученици, поделени по возраст. Иако тие биле дел од структурите на образовните центри, секое сиропиталиште било огранизирано внатрешно.

Престојот на децата бегалци во планинските одморалишта не траел долго. Во 1950-тите, со одлука на XXII централен комитет на Полската обединета работничка партија - ПЗПР (Polska zjednoczona partia robotnicza - PZPR) и Главниот одбор на Лигата на жени, сите деца биле преместени во Згожелец, каде што била формирана една институција за нив. Државниот образовен центар (ДОЦ) во Згожелец бил лоциран во комплекс од три објекти приспособени за оваа намена. Два од нив биле лоцирани во поранешните бараки, таканаречените

1 Податоци од 1995 г.

2 Според Петре Наковски, 1545 деца биле од македонско потекло, а 1472 од грчко потекло (Наковски 1987: 109).

3 Центрите биле финансирани од Министерството за образование, Министерството за здравство и Лигата на жени. Вацлав Копчињски (Wacław Kopczyński) бил одговорен за создавање и организирање на центрите во името на Министерството за образование. 
„бели бараки“ за деца на училишна возраст и „црвени бараки“ за најмалите деца. Третиот објект, за постара младина, којашто често посетувала стручни училишта, бил лоциран во областа Ујазд. „Белите бараки“ биле именувани по Никос Захариадис, додека стручното училиште во Ујазд било именувано по Лазо Трповски, македонски национален херој. Децата со белодробни заболувања биле сместени во санаториум во Рабка Здруј. Хенрик Орст бил директор на новосоздадениот ДОЦ.

Главната цел на новиот центар била да ги собере сите, околу 3200 деца заедно и да им обезбеди вистински услови за живот, развој и учење. Во формална смисла, организацијата на ДОЦ во Згожелец не се разликувала многу во однос на организацијата на претходните центри. Единствената промена, која значително влијаела на активностите на ДОЦ, било барањето за тесна соработка со грчката емиграциска заедница, назначувањето заменик-директор за грчки работи (со грчко потекло) и вработувањето на поранешни војници на ДАГ во центарот. Сите овие промени го промениле карактерот на центарот во полувоен, што довело до конфликт меѓу полските и грчките воспитувачи.

Државниот образовен центар во Згожелец, исто така, не постоел долг период. Бил затворен на крајот од август 1951 година, а поранешните бараки биле повторно заземени од војската. Децата, по летните кампови, биле преместени во новосоздадениот центар во Полице во близината на Шчеќин, како и во 10 други во Долна Шлезија (главно во Праце Одржански, Војанув, Шкларска Поремба и Легњица).

Многу години, Полице бил главниот образовен центар за деца од Грција. Објектите од поранешната фабрика за синтетички бензин биле адаптирани за оваа намена. Просторот од центарот, според Мјечислав Војецки (Mieczysław Wojecki), зафаќал 130 хектари, каде што биле сместени дури 130 станбени згради (Wojecki 1989: 37). До 1954 година, центарот во Полице бил главно место за престој на грчки и македонски деца во Полска. Од 1954 до 1958 година се работело само врз основа на старателство и образование на деца чии родители имале исклучително тешки услови за живот. Од 1958 година, исто така и деца од Полска почнале да бидат примани во центарот во Полице.

Најпредизвикувачка обврска за полските наставници и воспитувачи било организирањето на училиштето, што постојано се потенцирало во извештаите (Kopczyński 2008: 82). Тешкотиите произлегувале првенствено од националната и регионалната разновидност на децата (дури и деца од иста националност некогаш не се разбирале поради различните дијалекти). Друг фактор биле образовните недостатоци кај децата чиешто образование поради Втората светска војна и Граѓанската војна во Грција заостанувало. 
Затоа, повеќето деца биле поделени во класови според возраста, а не според степенот на знаење.

Она што е најважно, за презентиранава статија, е фактот дека децата во ДОЦ биле целосно одделени од полското население и од нивните македонски и грчки роднини. Одвојувањето од полското општество, особено во првата година од нивниот престој, било резултат на фактот што пристигнувањето на децата во Полска и во другите земји од Источниот блок било предмет на државна тајна 4 . Од друга страна, различниот начин на финансирање на престојот на возрасните и на децата во Полска довел до присилно раздвојување на овие две групи. Додека децата имале целосен престој: храна, сместување, медицинска нега, финансиран од државниот буџет, возрасните морале да заработат за живот на сопствените работни места што им биле понудени, како што се фабрики, државни земјоделски фарми и производствени задруги.

Како резултат на разделеноста, децата биле поподатливи за формирање од страна на наставниците и вработените во ДОЦ, што, за возврат, дало поголема можност за грешки и, во прв план, опасност од искоренување. Овој факт бил забележан од страна на Вацлав Копчињски (Wacław Kopczyński) во неговиот извештај за ДОЦ: „генерално нашите ученици претставуваат пластичен образовен материјал, што им овозможува да работат и да бидат насочувани. Има многу големи можности во ова моделирање, но и многу образовни опасности. Една од нив е и можноста за брза денационализација“ (Kopczyński 2008: 90).

\section{Локално знаење}

Опасноста од искоренување била резултат од прекинот на културната трансмисија. Еден однејзините елементи етаканареченото „локално знаење“. Многу автори ја истакнуваат важноста на локалното знаење и во историјата и во социологијата на знаењето и миграциските проучувања (Burke 2016; Lässig 2016). Локалното знаење, спротивно на формалното, се засновува на искуство и на директно пренесување.

Има малку податоци за локалното и неформалното знаење, вклучително и за традицијата и верувањата на македонските мигранти во Полска. Со сигурност може да се каже дека било пренесувано преку лични контакти во т.н. „грчки клубови“, кои постоеле речиси

4 Радио Слободна Европа ги обвинило грчките комунисти за киднапирање на децата. 
во секој град во кој биле населени грчки и македонски бегалци ${ }^{5}$ Кога се говори, пак, за децата, можеме да претпоставиме дека тие биле вклучени во многу мал дел на локалното македонско знаење како бегалци, вклучувајќи го и македонскиот јазик (во својата основна форма на користење како што е дијалектот). Во првиот период од нивниот престој во Полска, тие не можеле да го поминат дури ни летниот распуст со своите родители. Наместо дома, тие биле носени во училишни кампови или на село да им помагаат на земјоделците при жетвата во таканаречените „општествени акции“ (Wojecki 1989). Следствено, македонските деца многу брзо и лесно биле акултурирани во полската култура, која била пренесувана, главно, преку наставниците и образовните лица. Ова особено се случувало во текот на првата година од нивниот престој во Полска, кој поминувал во целосна издвоеност од нивните родители, кои сѐ уште биле во Грција. Ова прашање, исто така, е спомнато во извештајот на Вацлав Копчињски (Wacław Kopczyński) за Лондек Здруj (Lądek-Zdrój): „Ресурсите на знаењето, меѓутоа, се ограничени на мајчиниот јазик, и употребата на мајчиниот јазик што тие го користат е рудиментарна, на децата им недостигаат многу термини. Раскинувањето на врската со постарите македонски генерации ја предизвикало оваа состојба“ (Kopczyński 2008: 88).

Локалното знаење на македонските деца бегалци што биле сместени и згрижени во државните образовни центри (ДОЦ) било претставувано и пренесувано од страна на мајки. Сепак, многу од неговите аспекти не биле воопшто прифатливи за полските власти. Има неколку причини што довеле до оваа ситуација, меѓу кои и недостигот на знаења за миграциските проучувања и рефлексијата за плурализмот на знаењето (знаењата). Но една од нив изгледа дека била многу поважна од другите, а тоа била новата комунистичка идеологија, која била инфилтрирана во сите образовни и културни системи во поствоена Полска. Нејзините главни правила биле: наука и модернизација, секуларен модел на воспитување и фолклоризација на живата традиција.

Во веќе споменатиот извештај од ДОЦ, локалното знаење било во најголем дел применувано од страна на мајкийе и на него се гледало како на „примитивно“, така што мајкийе биле карактеризирани според нивниот „песимизам“, како и според „недостигот на социообразовна податливост“ (Kopczyński 2008: 88). Вацлав Копчињски (Wacław Kopczyński) строго укажува дека

5 Грчките клубови постоеле како дел од Здружението на политички бегалци „Никос Белојанис“ од Грција во Полска (телото што ги претставувало бегалците во Полска). Бројот на клупски соби се менувал во текот на годините: во 1961 година имало 29 клупски соби, во 1965 година - 30, во 1967 година - 27, а во 1968 година - 33. Архива на Институтот за национално сеќавање, AIPN BU 1585/22385 - Извештаи на финансискиот и сметководствениот преглед во здружението „Никос Белојанис“. 
„ние не можеме да ги толерираме навиките и образовните методи на нашите мајки“. Меѓу навиките тој ги наведува: „плукање в лице како образовен метод“, „тепање и врзување како образовен метод“ и „спиење со алиштата девет дена како израз на тагување“ (Kopczy区ski 2008: 88). На истата страница Копчињски пишува и за негативниот однос на мајкийе кон заболекарите, како и за нивното пасивно однесување како воспитувачки во градинката. Не се спомнува ниту еден позитивен фактор за нивното постоење.

Религијата, дефинитивно, била суштествен фактор на македонското локално знаење, но, повторно, забранета поради идеолошки причини. Не без жалење, ова го спомнува Копчињски:

„Децайа во Макеgонија се израснайи во религииозен

gух (...) сейак, мајкийе ја имале улог̄айа на иреносен

йојас йреку кој се йренесувале сийе суеверни религ̄иски

обичаи, койнежи, жалења, а йонеког̄аш и гेнев кон

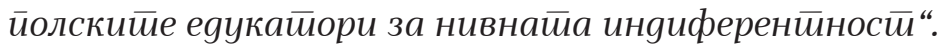

Полските власти не само што забраниле секакви религиозни практики туку и ги замениле со идеолошко образование, одземајќи им ги на децата сите религиозни белези.

Секуларизацијата вклучила нова организација на ритуалната година. Божиќ, Велигден и другите верски празници биле заменети со национални. Се китело елка за новогодишната ноќ. На тој ден, советскиот еквивалент на свети Никола, Деg Мороз, доаѓал кај децата со поздрави од „драгиот сакан другар Сталин“, носејќи подароци „од другарот Бјерут"7.

Еден од столбовите на образовниот план во државните образовни центри било таканареченото „естетско образование“. Тоа вклучувало учење песни, танци, свирење инструменти, како и украсувањенадетскитедомовиирачниизработки.Сепак, „репертоарот на песни, танци, украсни мотиви“ претставуван од мајкииее е опишан како „многу примитивен“, на сите нивоа: „техника, ниво и изведба“. Затоа, од првата година на престојот во Полска, децата учеле полски народни танци и песни, како и песни од комунистичкиот репертоар (на пр. Интернационалата). Македонските елементи биле делумно вклучени, но „поддржани, подигнати на повисоко ниво“ (Kopczyński 2008: 112) што претставувало преработување според упатствата на социјалистичките кореографи ${ }^{8}$

6 За оваа практика се раскажува со жалење во интервјуата затоа што крстовите или светите слики често биле единствените спомени од семејната куќа.

7 Полски национални архиви: APSz, 56o/15 - Извештај за третиот квартал на Домот за деца бр. 10, Државен образовен центар во Плаковице.

8 Овој процес се одвивал во цела повоена Полска, кога автентичната народна уметност и живите селски традиции не биле ценети и биле заменети со фолклоризам, како што се сценски ансамбли што изведувале народни песни и танци инспирирани од различни региони. Народната уметност и занаетчиството требало да послужат за 
Одговорот на полските власти на сите тие „примитивни“ однесувања од страна на мајкийе била полонизацијата на децата. Вацлав Копчињски пишува:

„Ние не сакаме gа гेи йолонизираме, а во исйо време

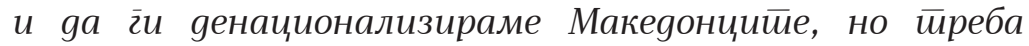
gа гेи йолонизираме еgуцирајќи г̄u gецайа со цел gа г̄u

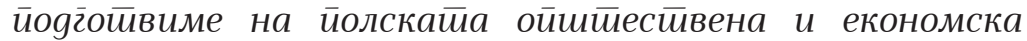
околина како ияни грраgийели на Макеgонија. Нема gруг̄

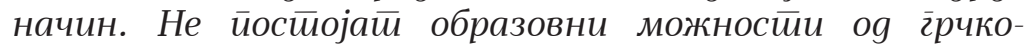
макеgонскайа сиирана“" (Kopczyński 2008: 98).

Доказот за брзата полонизација е фактот што, кога возрасните бегалци пристигнале во Полска во 1949 година, децата служеле како преведувачи меѓу Полјаците, Македонците и Грците. Еден од нив, млад Македонец, се сеќава на патувањата во Меѓугорje (Międzygórze) што ги направиле тој и неговиот учител:

„[Јас бев во Меѓуг̃opje] како йревеgувач.

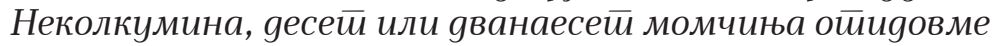
йаму. Зайоа шиио неколку илјаgи gојgоа ов Гриија! Овие луѓе изг̃леgаа ужасно! Шйо сѐ немаа со нив! Беше нейоимливо! Тие носеа бојлери, иениериња и некој йрибор за гойвење найравен оg глина! Некој леб, не знам

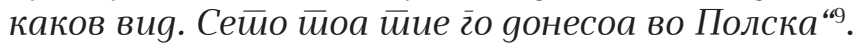

Горенаведената нарација го покажува растечкиот јаз меѓу децата и возрасните бегалци. Потсмевачкиот тон со кој младиот Македонец го опишува изгледот и опремата на возрасните докажува дека тој веќе го презел начинот на перципирање на полските наставници и воспитувачи, да може да разликува „примитивен“ од „цивилизиран“"10.

\section{Моќта на знаењето}

Прашањето за (присилното) полонизирање на децата носи друг концепт поврзан со социологијата и историјата на знаењето: врска помеѓу знаењето и моќта. Ова прашање стана еден од централните аспекти на многу анализи од областа на историјата на знаењето (Lässig 2016), особено во врска со колонијализмот и

поголемата идеја за (хомогена) нација, додека „руралната традиција била идентификувана со заостанатоста и суеверието, а модернизацијата и индустријализацијата станале главна цел на економската политика на штета на развојот на земјоделството“ (Kordjak 2016: 13).

9 Интервју со Ираклис Поповски, 6.1.2011 година, Полска.

10 Иако социолозите на знаењето сѐ повеќе пишуваат за децата како преведувачи на мигрантската култура и нивната исклучително важна улога во мигрантскиот свет како некои „што се помеѓу“ (Lässig 2016: 30). 
постколонијализмот. „Тензијата помеѓу знаењето и моќта“ ги носи идеите за културните хиерархии и социјалните нееднаквости како „централни за разбирањето на знаењето како историски феномен“ (Lässig 2016: 37).

Македонските бегалци во Полска, кои биле, според моето истражување, во постојана состојба на „малцинство во малцинство“ (Kurpiel 2015), останале во двојна зависност: од Полјаците и од Грците. Полјаците го организирале престојот во земјата и главно биле одговорни за образованието и воспитувањето на децата, додека Грците продолжиле да ги држат највисоките функции во сите организации во егзил. Едностраната распределба на моќта резултирала со неправедна дистрибуција на знаењето меѓу бегалците од Грција во Полска.

Другиот клучен аспект што влијаел на судбината на Македонците во Полска (и во другите источноевропски земји) била повоената геополитика, од која најважен бил конфликтот меѓу Тито и Сталин и исклучувањето на Југославија од Информбирото во 1948 година. Полската и грчката комунистичка партија припаѓале на „блокот СССР“, а Југославија во првите години од престојот на бегалците во Полска била претставена како главен непријател. Сѐ што било поврзано со Југославија се сметало за непријателско и со тоа забрането. Тука не биле вклучени само македонските организации од Втората светска војна или грчката граѓанска војна (НОФ, АФЖ коишто биле распуштени) туку и македонскиот литературен јазик во чијашто кодификација голема улога имал Блаже Конески. Од таа причина, на македонските бегалци во егзил им бил понуден нов јазик: т.н. „славомакедонски“. Весниците, учебниците за деца и сите документи за Македонците се напишани на славомакедонски јазик. Новиот, но политички коректен јазик бил, всушност, смеса од македонски и бугарски јазик напишан со бугарска азбука ${ }^{11}$. Сите вести од Социјалистичка Република Македонија, вклучително и оние од семејствата, биле забранети, цензурирани или искривени со политичката пропаганда.

\section{„Идентитетски пресврт(и)“}

Сепак, полските наставници и официјални лица поддржувале еден вид локално знаење - чувството за националната припадност на мигрантите. Полските наставници и воспитувачи многу рано ги

11 Бугарија, тоа време поврзана со СССР, била предложена како решение за оние Македонци што се чувствувале лошо во Полска и сакале да живеат во балканска држава. Меѓутоа, многу бегалци имале роднини што живееле во југословенската, „лошата“ Република Македонија. 
препознале Македонците како посебна нација и ги поддржувале нивните напори за самоидентификација. Покрај тоа, да се биде „цивилизиран“ или „научно ориентиран“ за Полјаците значело тие да останат неутрални. Понатаму, неутралноста донесла нова вредност во поларизираното грчко-македонско општество на бегалците, во кое националните антагонизми влијаеле и врз децата и врз родителите. Грчките официјални лица во егзил го продолжиле процесот на хеленизација на Македонците: со преведување на нивните имиња и презимиња на грчки јазик или со блокирање на можноста за македонско самоорганизирање одвоено од грчките врсници.

Признавањето на Македонците како посебна нација, како и императивот да останат неутрални довеле до нова ситуација за Македонците, особено за децата. Полските власти започнале да ги третираат како посебна група и им обезбедиле македонски училиштен систем, кој вклучувал курсеви за деца (јазик, литература, историја на нацијата), како и обуки за наставници.

„Пресвртот на идентитетот“ на Македонците во Полска се појавил во два брана. Првиот се случил кратко по нивното пристигнување во Полска кога Полјаците ја забележале изразената националност на Македонците. Како што читаме во извештајот на Вацлав Копчињски:

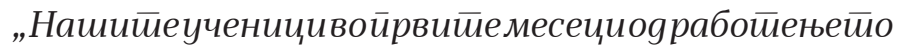

ни йрейсииавија неиздиференциран национален

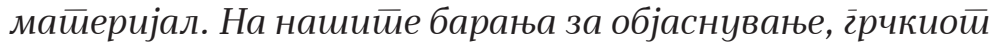
менаименй (Румелойис и Лили Васос) оgг̄оворил gека йоголемиой gел се Макеgонци, а йомалиой gел се Грци.

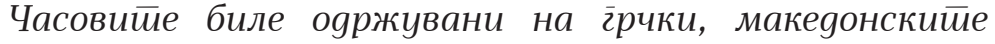

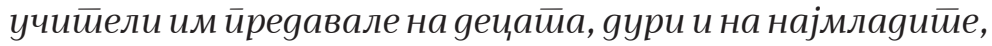

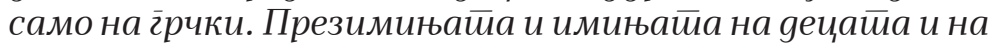
мајкиие биле gаgени само на грчки. Румелойис и Лили Васос (...) намерно г̄и хеленизирале gецайа“" (Kopczyński

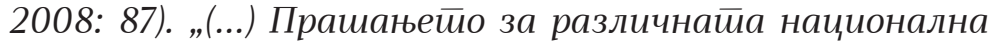

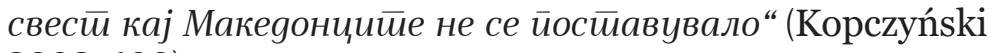
2008: 100).

Сепак, посетата на Комисијата од Министерството за образование ја променила оваа состојба. Како последица на нејзината одлука, сите македонски деца во Полска требало да го научат својот мајчин јазик - македонскиот. Покрај тоа, училиштето организирано во државните образовни центри морало да биде тријазично: на полски, на грчки и на македонски (Kopczyński 2008: 100). Тоа било, според Копчињски, почеток на будењето на националната посебност меѓу Македонците во Полска.

Македонскиот јазик бил воведен во училишната програма за децата во Лондек Здруі заедно со полскиот и грчкиот јазик. Истовремено, започнала постапката иницирана од една од 
воспитувачките, Олга Поповска, за враќање на македонските имиња на децата. Како што пишува Копчињски: „Олга, која во тие денови се преобрази од Пайа во Пойовска, започна да ги менува имињата од грчки во македонски, сега завршуваат претежно со -ски и -цки“ (Kopczyński 2008: 91). Во тоа време Христу станало (повторно) Ристовски, Гагацис - Гагачовски, Лазар - Лазовски итн. ${ }^{12}$

Учењето македонски јазик било поврзано со потребата од едукација на наставниот кадар. Наставниците биле регрутирани од група македонски емигранти. Отпрвин, самите партизани или мајкиие е чувари станале наставници, а набрзо потоа, во втората половина на 1950-тите, студентите што се школувале во Полска завршиле педагошки курсеви и средни училишта. Првиот курс за обука на наставници се одржал од 15 јули до 15 септември 1949 година во Солице (Шчавно) Здруј (Solice (Szczawno) Zdrój). Следните се реализирале секоја година за време на летниот распуст. Покрај учењето македонски, полски јазик и основите на детската психологија и педагогија, курсевите вклучувале и предавања за меѓународната политичка состојба и „историјата на нацијата“ (Наковски 2008б).

\section{Втор пресврт, случајот со македонските учебници}

Вториот бран на македонскиот „пресврт на идентитетот“ во Полска бил поврзан со политичките промени, имено со одмрзнувањето на односите со Хрушчов. Негова најдобра илустрација е случајот со македонските учебници што започнале да се печатат во Полска.

До 1956 година, сите учебници биле објавени на веќе споменатиот славомакедонски јазик - вештачки создаден од грчките комунисти за да ги разликуваат Македонците од Грција од оние што живееле во Југославија. За време на првите години од нивниот престој во Полска, македонските деца користеле учебници испратени од Букурешт, каде што, по барање на Централниот комитет на Комунистичката партија, биле печатени образовни и училишни помагала што биле испраќани во сите земји на народната демократија. Од 1955 година, учебниците за македонските деца на почетокот биле печатени од полската државна издавачка күќа за училишни материјали: македонска граматика (обновено издание на издавачката куќa Неа Елада од 1953 година), потоа македонски буквар и читанки за основното образование (врз основа на прирачникот објавен од Неа Елада од 1950 година) и читанки за II и III одделение. Министерот за образование побарал да се изврши преглед на сите учебници и на

12 Прашањето за македонските презимиња и нивната грчка или македонска форма било поставено неколку пати, исто така, за време на состаноците на вработените во воените сили во Згожелец. 
букварот. Сепак, рецензентите, кои не го знаеле македонскиот јазик, не биле во можност да го проценат квалитетот на книгите.

Затоа било големо изненадување за полските власти кога, во 1956 година, на летен курс за настава во полиција, македонските наставници, охрабрени од настаните во Полска и КПГ, објавиле дека славомакедонскиот јазик, кој биле принудени да го користат во егзил дотогаш во Полска, имал малку заедничко со македонскиот литературен јазик. Тоа предизвикало одредена конфузија во Министерството за образование, како што било потврдено во следното писмо:

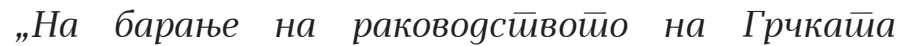
асоцијација на бегалии во Полска, Минисиерсиивойо

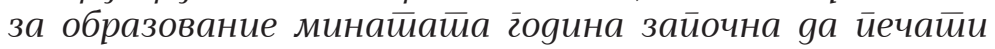
македонски учебници (...) Минисиересиивойо за образование, йри иеччайењейо на овие учебници, беше убеgено, йоg влијание на ірчкийе и макеgонскийе gруг̃ари, gека макеgонскииее книг̃и се найишани

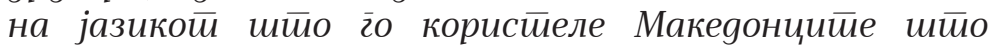

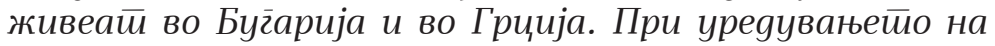

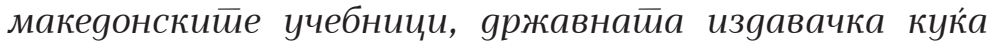
за учебници користетела макеgонски книг̃ објавени во

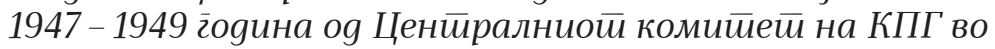
Букурешй.

На леиеен курс во јули гооинава, макеgонскииее насииавници, кои досегіа не беа gел о о образовниой йроцес

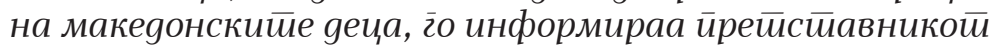

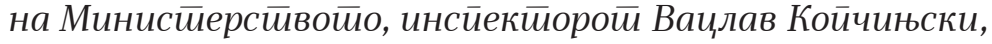

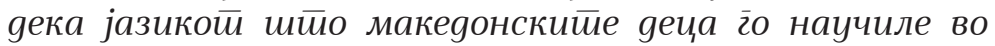

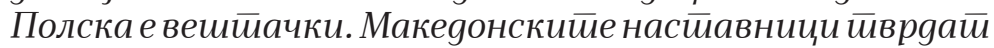
gека грчкийе gругіари созgале нов макеgонски јазик во

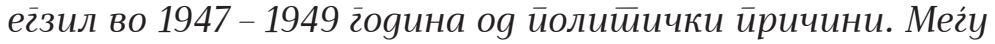

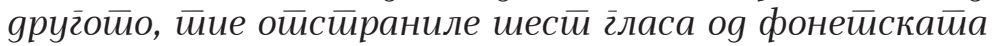
азбука и гेи замениле со тири бугіарски и йри руски. Во

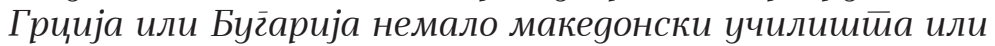

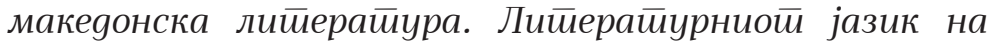

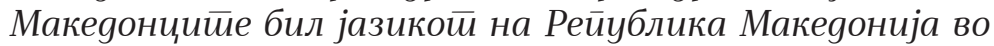

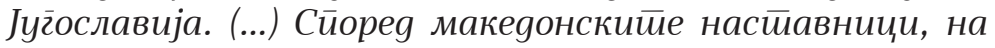

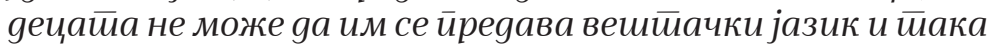

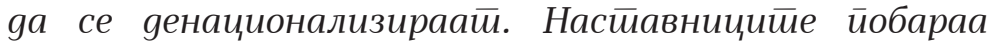
gа се зайре йечайењейо на макеgонски учебници сѐ gоgека макеgонскайа инйелигенција конечно не ја

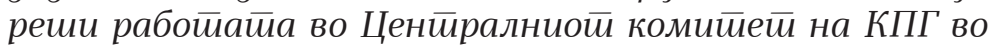
Букуреши" “(Наковски 2008а).

Со оглед на горенаведеното, збунетото Министерство одлучило да престане да го печати македонскиот буквар и учебниците и, наместо 
тоа, донесло одлука да донесе македонски учебници од Југославија за да се процени нивната содржина и јазик. Коле Симитчиев, македонски бегалец во Полска и професор по славистика, ја направил проценката. За жал, неговиот преглед посочил дека југословенските учебници не се соодветни за македонските деца во Полска. Тој навел две значајни причини: лексичката (некои читанки биле испечатени на српскохрватски јазик) и политичката (многу читанки се однесувале на информациите за Јосип Броз Тито и за југословенската федерација).

По негативната оценка на учебниците од Југославија, Министерството одлучило да ги објави сите учебници наново. Главен уредник на новите учебници, кој ја надгледувал работата на државната издавачка куќа, бил Пандо Папахристу (мак. Шапкарев).

\section{Содржина на учебниците и нивна кратка анализа}

Два од учебниците достапни во Националната библиотека и објавени од државната издавачката куќа за учебници пред да биде отворено „прашањето за јазикот“ од страна на македонските наставници биле испечатени на славомакедонски јазик: Буквар

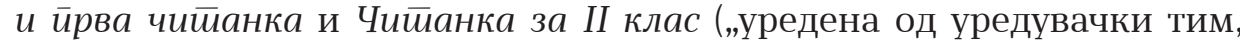
уредена од Пандо Папахристу“), исто така од 1956 година ${ }^{13}$. И двата учебника биле повторно објавени на македонски литературен јазик. Новите изданија биле, соодветно: Буквар и йрва чийанка, уредник Пандо Шапкарев, 1958 година, и Чийанка за II оggеление, подготвена од уредничкиот тим, преведена на македонски јазик од П. Бандилов и П. Папахристу, уредник Пандо Папахристу, 1958 година.

Во Букварой измените се целосно видливи бидејќи е сочинет главно од азбуката и едноставни текстови што кореспондираат со секоја од буквите во неа. Но, наместо тврдиот знак, во изданието од 1958 година ја има буквата $\mathbf{j}$, наместо бугарското й, македонското џ,

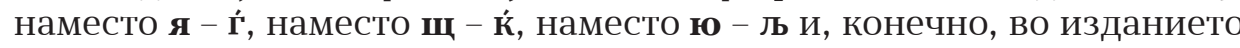
од 1958 година била додадена буквата $\mathbf{s}$. Во однос на лексиката, разликите се мали. Во 1956 година, зборот gом што се појавува во Букварот е заменет со зборот куќа, зборот забавачница е заменет со

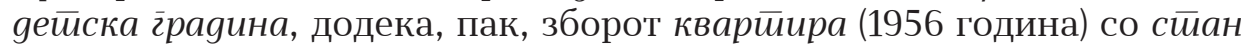
(1958 година).

13 Третата објавена книга на славомакедонски јазик била граматика: Граматика на македонско език: фоннетика, морфологија, без спомнат уредник, 1956. Сепак, решив да не ја анализирам оваа книга бидејќи немам доволно компетенции. Другите книги што не ги анализирам во рамките на овој труд (од истите причини) биле објавени на официјален македонски јазик: Примери од македонската литература за VII одделение, уредници: К. Симитчиев, П. Шапкарев (Папахристу), 1959, Примери од литературата за средните школи, уредници: К. Симитчиев, П. Шапкарев, 1964, и Македонски народни приказни, уредник Пандо Шапкарев, 1966 година. 
И во двете изданија на Букварой била презентирана идеолошка и патриотска содржина, на пример, текст за Гоце Делчев и Јане Сандански, како и за Први мај. Меѓутоа, во изданието од 1958 година, два текста - „Варшава“ и „Петокрака“ - се изоставени.

Визуелниот изглед на двете едиции останал неизменет - двете изданија биле илустрирани од страна на J. Королкевич (J. Korolkiewicz). Доминираат полската природа и полските пејзажи. Исклучок е сликата на осмата страница што претставува елементи од руралниот пејзаж во Грција: поле, магаре и некои растенија, вклучително лози и смокви. (На претходната страница е прикажан сличен полски пејзаж со популарните зеленчуци во Полска: зелка, компири и кромид.)

Што се однесува до обете изданија на читанките за II одделение, разликитебиле првенствено во азбучниот запис, а помалку лексички. Содржината на учебниците и нивното уредување останале непроменети. И двата учебника содржат првенствено дидактички и морализирачки, како и патриотски и идеолошки текстови. Во втората категорија текстови треба да се спомнат: текстот за Лазо Трповски, поемата „А бре Македонче“ и текстот „Кирил и Методиј“. Како илустрација за текстот „Новогодишната елка“ е насликан Ленин како воспитува деца.

Како што се наближува делот од локалното знаење, треба да се спомне дека тесктот „Мојата куќа“ започнува со овие зборови: „Јас често се сеќавам на нашиот дом и село - вели постариот брат на Мице. Многу е мало, но многу убаво“ (стр. 9). Оваа реченица е проследена со опис на куќата и природата (вклучувајќи и растенија) околу неа.

Веројатно поради фактот што учебникот од 1958 година бил само препишан на официјалниот македонски јазик и како резултат на потребата за ажурирање на содржината, учебникот за второ одделение бил издаден одново во 1964 година. Тој веќе бил дело на Пандо Шапкарев (во овој учебник неговото презиме се појавува само во македонска верзија) со променетиот изглед. Повеќето текстови сѐ уште презентираат некомплициран дидактички и морализирачки материјал. Текстовите за големата Октомвриска револуција (стр. 25) и за Ленин (стр. 26) биле додадени како идеолошка содржина. А од патриотската содржина, исклучително е интересен текстот „Убава е нашата татковина“. Во него читаме:

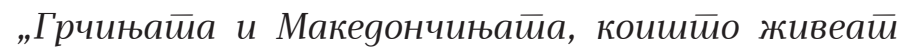

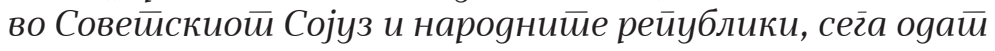

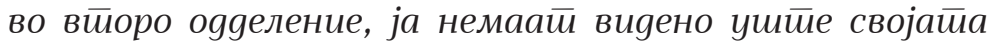

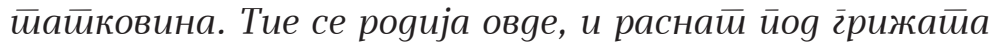

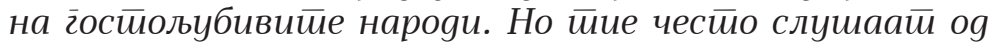

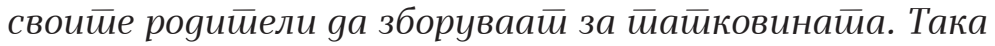
и йие знаай мног̄у за неа“ (стр. 27).

Интересно е, сепак, што првото дете споменато во текстот е Костакис, кој честопати слушал за Атина од неговите родители. 
Родителите на Костакис, родени во „столицата на нашата татковина“, му кажуваат за нејзините привлечности: пријатна клима без зими и мразови, како и споменици: Акропол и Пантеон. Маро, чии родители се од островите, се споменува како втор. Дури на трето место малите Македонци читаат за Коле, кој е костурчанец. Неговите родители биле родени во регионот на Касторија, каде што „се бореле против германските фашисти што дојдоа да ја поробат нашата татковина“ (стр. 28). Во близина се наоѓаат Лерин и Леринското Поле, каде што зреат вкусни, слатки јаболка и други плодови. Голема и вкусна риба плива во Костурското Езеро. Текстот завршува со заклучната реченица: „И нема дете од второ одделение, коешто да нема чуено за неа (татковината заб.) (...) каде војуваа смелите партизани, нашите родители, против туѓите фашисти - за слобода на татковината“, а домашната задача гласи: „напишете од кое место на нашата татковина сте вие и што знаете за него“.

Друг текст, овојпат што се однесува само на Егејска Македонија, е „Од Лерин до Солун“ (стр. 29-33). Тоа е приказна за Васил, кој патувал во Солун со неговиот татко. Разгледувањето на пределот е според приказната на татко му, поминувајќи низ градовите, за растенијата и за животните што се гледаат од прозорецот на возот.

Покрај горенаведените текстови, учебникот содржи стандардни текстови за Гоце Делчев, Илинден, Јане Сандански и Лазо Трповски. Новина е текстот за 25 Март - „празник на братскиот грчки народ“ (стр. 111).

Во учебникот Читанка за III одделение, подготвен од уреднички тим, странските текстови се преведени на македонски јазик од П. Бандилов, Р. Маркозанов, Т. Белчев, П. Шапкарев (Папахристу), уредник Пандо Шапкарев (Папахристу), со малку поинаков изглед. Песните зафаќаат многу содржина, како и „македонските народни песни“. Сѐ повеќе содржини има за патриотските призвуци (на пр. за Крушевската Република), како и илустрации што го прикажуваат руралниот живот во Грција. На страница 32 има поема „Моето село“, што почнува со зборовите: „Далеку на југ, таму“. На страница 13, малите Македонци можеле да ја прочитаат народната песна „Планино, Пирин Планино“, за Пирин Планина, а на страниците 5556 текстот „Партизанска жетва“, за жетвата од 1948 година, т.е. за време на грчката граѓанска војна.

Бизарен, особено од гледна точка на современото образование, е текстот „Писмо од санаториумот“ на страниците 60-62. Приказната започнува со пристигнувањето на едно писмо до одредено семејство од најстарата ќерка и сестра, Јорданка, која е во болница. Јорданка во него пишува дека операцијата на нејзината болна, пократка нога била успешна и дека има нова пријателка од Букурешт, на која ѝ раскажува за „нашето село и нашата татковина“. Откако го прочитала писмото, мајката се расплакала. На прашањето од децата за причината за 
солзите, мајката со радост одговара дека луѓето што живеат во Советскиот Сојуз и во другите народни републики имаат можност да се лекуваат, и затоа е сигурна за здравјето на нивните деца. Наспроти ова, „само луѓето што имаат пари се лекуваат во нивната татковина“. Текстот покажува јасна дивергенција, предизвикувајќи одредена вознемиреност: од една страна, Јорданка, лежејќи во болница, ѝ раскажува на пријателката од Букурешт за селото, веројатно лоцирано во Егејска Македонија, и токму таму сака да ја покани на лето, а, од друга страна, семејството живее во една од земјите на Источниот блок и цени некои аспекти (на пр. здравствена заштита).

Покрај горенаведените текстови, учебникот има и текстови со идеолошка содржина во кои се истакнува љубовта кон Советскиот Сојуз, како што се „Ленин и дете“ (стр. 98-99) или „Што се случи во Глиник“ (село во Полска), за Советската армија (стр. 101-103) или „Пионер“ (стр. 153-154). Сепак, како и во учебниците за пониските одделенија, многу простор им е отстапен на текстовите за природата, годишните времиња и нивната привлечност. Овој вид содржина исчезнува кај читанките во повисоките одделенија.

Учебникот за IV одделение, подготвен од уредничка екипа; странски текстови преведени на македонски јазик од П. Шапкарев (Папахристу), К. Симитчиев; уредник: Пандо Шапкарев (Папахристу), е помалку илустриран, додека текстовите се подолги. Повеќето од нив се однесуваат на она што можеме да го наречеме „патриотска географија“: на пр., поемата „Пирин“ или текстот „Пирин Планина“, кој почнува со зборовите „Убава е нашата Пирин Планина!“. Интересно, ова е еден од првите текстови за места лоцирани надвор од Егејска Македонија и Грција, што, се чини, дека ја третира целата област на поделена Македонија како татковина. Ваквите толкувања може да бидат сугерирани со прашањата во читанката: „Знаете ли каде се наоѓ Пирин Планина? А Егејското Море? А што знаете за Вардар?“. Други „патриотско-географски“ текстови се: „Атина“ (стр. 120-123), која започнува со зборовите: „Кој нема слушнато за Атина, главниот град на Грција“, и „Костур“, како и текстот за „Селото Гуменџа“ (грч. Goumenissa). На страница 130 е прикажана жена во македонска носија, од Дебарско, и поемата „Татковина“, но нема прецизни информации за која татковина е поемата.

Различен и нов дел, во споредба со претходните текстови, се занимава со историјата на Македонците. Започнува со текст за Илирите и Тракијците: „Нашата земја пред доаѓањето на Словените“ (стр. 142), потоа „Македонските Словени и Византија“ (стр. 144), неколку текстови за Македонија под турска окупација, песна за Карпош (стр. 150-154), текст „Борба против грчкото духовно ропство“ (стр. 155156), за ВМРО (стр. 158), за Гоце Делчев (стр. 160), за Илинденското востание (стр. 166-167), за Питу Гули, Јане Сандански, Лазо Трповски и за Воденицата на дедо Груев, за Националноослободителниот фронт 
(ЕАM) (стр. 189). Оваа серија завршува со текстови за локалните херои, неколку текстови за Мирка Гинова ${ }^{14}$, Пандо Шиперков, борец на ДАГ (стр. 203), Никос Белојанис, како и со поемата „Бегалци“. Како и во претходните учебници, има неколку текстови за Советскиот Сојуз (стр. 215) и неговите достигнувања, на пример, за комбајнот (стр. 261).

Во учебник за V одделение (ур. Пандо Шапкарев, 1964) се променува карактерот на текстовите. Иако уредникот е ист (неговото име е напишано само на македонски јазик), учебникот престанува да биде дело на неговиот автор. Во содржината доминираат преводи на текстови од познати (воопшто, или од тоа време) писатели и поети: Максим Горки, Лав Толстој, Јон Лука Караџале ${ }^{15}$, Аркадиј Гајдар ${ }^{16}$, Александар Пушкин, бајките на Езоп, па дури и Виктор Иго. Целиот учебник е поделен на пет тематски области. Првата има наслов „Училиште“ и ги содржи повеќето преведени текстови, како и текстови за Архимед и Галилеј и поемата „Москва“.

Вториот дел е „Татковина“. Вклучува текстови како што се: „Загоричани, родното село на Димитар Благоев“, „Охридското и Преспанското Езеро“, „Шар Планина“, „Долината на Темпи“ (село, кое сега на грчки е Темпе), „Олимп и Кисав“, „Татковино, ти си како здравје“ од Иван Цанкар ${ }^{17}$, како и песни од Рајко Жинзифов ${ }^{18}$.

Третиот дел „Народно творештво“ содржи народни приказни и народни песни. Четвртиот е насловен „Борба“. Содржи текстови за ајдуци, за кралот Марко, „Смртта на Гоце Делчев“, за Никола Карев ${ }^{19}$, Илинденското востание и Крушевската Република. Насловот на последната глава е „Работа и труд“. Содржи текстови за луѓе и работа, овојпат без територијални ограничувања, на пример, түка наоѓаме текст за малото црно момче Том, чистач на чевли.

Државната издавачка куќа за училишни материјали објавила двапати учебник за VI одделение: во 1958 и 1968 година. Првиот од 1958 година, кој бил подготвен од Коле Симитчиев, странските текстови биле преведени на македонски јазик од К. Симитчиев, а уреден од Пандо Шапкарев (Папахристу), може да се смета како учебник за литература и историја на Македонија, првенствено на егејскиот

14 Мирка Гинова (1916 - 1946) била наставничка, а подоцна и борец за време на Втората светска војна и грчката граѓанска војна. Таа е првата жена убиена во Грција од политички причини.

15 Романски драмски писател, романсиер, поет и новинар.

16 Советски писател за млади.

17 Словенечки писател, претставник на словенечкото модернистичко движење, и поет.

18 Поет и преведувач од Велес.

19 Револуционер и организатор на Илинденското востание во 1903 г. за ослободување на Македонија. 
дел. Започнува со поемата „Татковина“ од Паскал Паскалевски, македонски поет и писател што пишувал за Егејска Македонија. Во целиот учебник можеме да најдеме неколку негови песни. Во текстовите се обработени теми за развојот на македонската култура и македонската историја. Учебникот започнува со текстот „Браќата Кирил и Методија и нивното дело“ и оди хронолошки преку свети Наум, „Хајдук“, „Карпошово востание“, текст за Солун, Гоце Делчев и востанието во Смилево. На страница 30 има фотографија на жена во народна носија од Драчево, додека на страница 48 има цртеж што прикажува типична македонска улица од Охрид. Прирачникот содржи и текстови од грчки автори, на пр. од Ели Алексиу (стр. 71) и Ригас Фереос (стр. 74). Интересно е што на крајот е додаден македонскополски речник.

Изданието од 1968 година, уредено од Панде Шапкарев, вториот прирачник за шесто одделение, има целосно различен карактер. Тој е збирка на народни песни, поеми и фрагменти од текстови на познати локални поети и писатели, вклучувајќи ги Никос Казанзакис ${ }^{20}$, Коле Чашуле ${ }^{21}$ и Григор Ставрев Прличев ${ }^{22}$. Последните учебници за седмо и осмо одделение биле објавени во 1966 година. Не е познато кој ги уредувал, можеби затоа што тие содржат само извадоци од литературата и поезијата.

\section{Заклучок}

„Учебницийе“, йишува Зимоне Лесиг (Simone

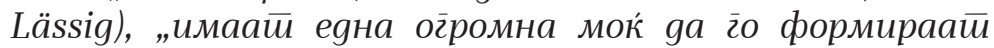

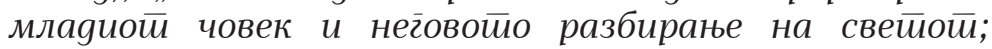

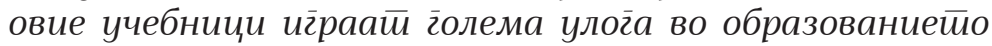

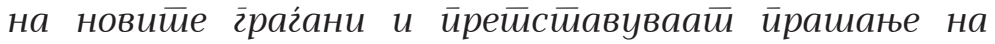

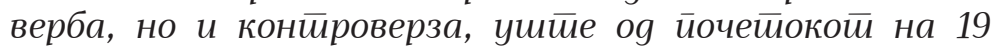

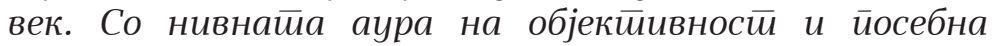

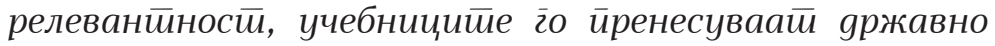

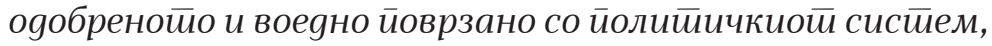

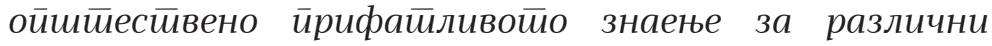

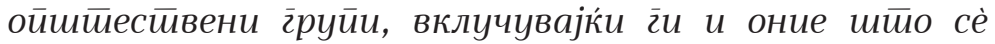

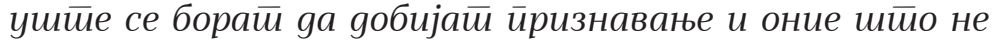
веруваай во вакво официјално знаење. Во иеериоgи на

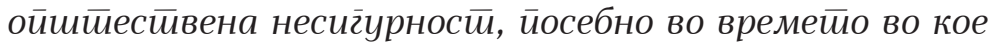

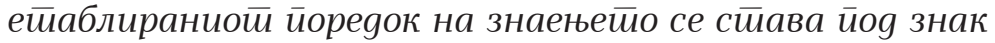
за йрашање, а новиой йореgок на знаење се формира,

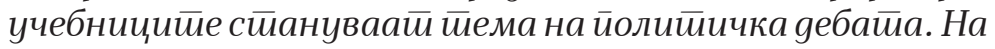

20 Грчки романсиер, поет, драматург, преведувач и мислител.

21 Македонски романсиер, драматург, публицист, револуционер борец, политичар и дипломат.

22 Македонски автор од периодот на романтизмот и значаен претставник на македонската литература од 19 век. 


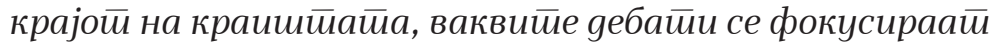

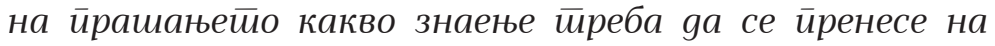

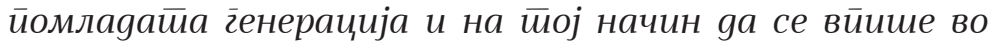

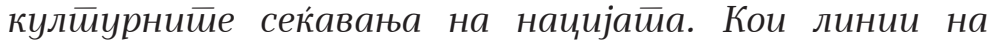

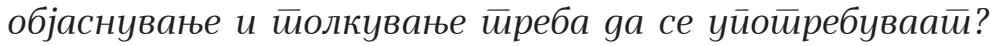

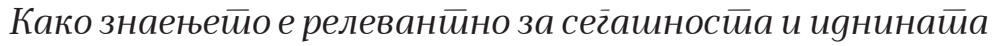

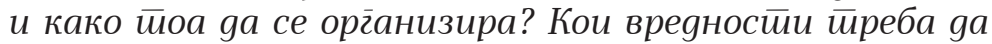
бияай основа за социјална кохезија?“(Lässig 2016: 41).

Случајот со македонските учебници отпечатени во Полска е совршена илустрација за македонската судбина во Полска воопшто, особено за дистрибуцијата на знаење меѓу оваа група. На почетокот, учебниците биле отпечатени на вештачки славомакедонски јазик, а потоа биле објавени одново од македонски уредници што живеат во Полска, што било можно поради меѓународните и внатрешните промени во земјите од Источниот блок ${ }^{23}$.

На новите учебници може да се гледа како на следен и важен чекор во пресвртот во идентитетот на угнетено малцинство, што се случил благодарение на нивните напори, како и на поволниот став на Полјаците. Новите книги биле отпечатени на официјален македонски јазик и содржат многу информации за Македонците, за нивната историја, фолклор и литература. Сигурно, тие го поддржувале патриотското образование и, на тој начин, националниот идентитет на младите Македонци во егзил.

Сепак, новите учебници не биле кохерентни, веројатно од политички причини. Сликата за „татковината“ не е јасна. Дали е тоа цела Грција или само Егејска Македонија? Или целиот регион на Македонија поделен на три дела? Има многу работи за Атина, иако ниту едно од децата не било оттаму, но ништо за Скопје, градот во кој многу деца имале свои роднини. Историјата на македонската нација е кохерентна со претставите за Република Македонија (со важните херои како Карпош, Гоце Делчев и настаните: Илинденско востание, Крушевска Република). Сепак, некои текстови раскажуваат за грчките празници. Оваа недоследност не одговарала на реалната состојба на Македонците во Полска, за која, како што беше прикажано во моето претходно истражување, во втората половина на 1950-тите, Социјалистичка Република Македонија била примарна, идеолошка татковина (Kurpiel 2015). Најзначителниот број Македонци од Полска мигрирале таму, охрабрени од можноста за употреба на македонскиот јазик и за изразување на нивниот национален идентитет. Многу од нив имале роднини во Скопје или во други градови.

Некохерентната содржина на учебниците може да се толкува и како самоцензура на нивните уредници, кои, како што споменав

23 Интересниот антрополошки и јазичен аспект на славомакедонскиот јазик во учебниците е прашање на лингвистичкиот поглед (слика) на светот. Сепак, тука не може да се разработи поради ограничувањата на статијата. 
претходно, биле во постојана состојба на малцинство во малцинството, престојувајќи меѓу Полјаците и Грците. Нивната задача била многу тешка и во согласност со комплицираната судбина на егејските Македонци, родени во Грција, израснати во социјалистичка Полска.

Покрај тоа, учебниците се печатени предоцна. И покрај конечниот успех, како резултат на проблемите со учебниците, македонските деца немале училишна поддршка или ја имале многу ограничено до крајот на 1950-тите, т.е. во периодот на најголемата потреба за нив. Многу од учебниците биле користени од децата веќе родени во Полска, додека, пак, децата што дошле од Грција биле лишени од ова и биле образовани на силно идеолошки начин. Тоа довело до силна полонизација на македонските деца и прекинување на ширењето на локалното знаење.

Она што се чини дека е најавтентично е претставата за татковината според природата: планините, езерата или растенијата. Оваа стратегија, за жал ограничена, се чини дека соодветствува со вистинското искуство за татковината што постои во сеќавањата на децата бегалци за нивното детство во руралните области на Северна Грција.

\section{Литература}

Burke, Peter. 2016. What Is the History of Knowledge? What Is History? Cambridge ; Malden: Polity Press.

Danforth, Loring M., and Riki van Boeschoten. 2012. Children of the Greek Civil War: Refugees and the Politics of Memory. Chicago, London: The University of Chicago Press.

Kopczyński, Wacław. 2008. "Sprawozdanie Dyrektora Naczelnego Państwowego Ośrodka Wychowawczego, Magistra Wacława Kopczyńskiego, Dotyczące Przyjęcia Dzieci z Macedonii Egejskiej.” In Macedońscy Uchodźcy w Polsce. Dokumenty 1948-1975, edited by Petre Nakovski, I:70-125. Skopje: Arhiv na Makedonia.

-—-. n.d. "Dzieci Macedońskie w Polsce, Rękopis."

Kordjak, Joanna. 2016. "Polska - Kraj Folkloru?” In Polska- Kraj Folkloru?, by Joanna Kordjak, 11-40. Warszawa: Zacheta-Narodowa Galeria Sztuki.

Kurpiel, Anna. 2015. Cztery nazwiska, dwa imiona: macedońscy uchodźcy wojenni na Dolnym Ślasku. Poznań: Wydawnictwo Nauka i Innowacje.

Lässig, Simone. 2016. "The History of Knowledge and the Expansion of the Historical Research Agenda." Bulletin of German Historical Institute 59: 2959. 
Nakovski, Petre. 1987. Makedonski Deca vo Polska (1948-1968): Politikološka Studija. Skopje: Mlad borec.

---, ed. 2008a. "List Do Ministra Oświaty Zawierający Żadanie Przerwania Druku Podręczników Macedońskich, Warszawa 10.08.1956.” In Macedońscy Uchodźcy w Polsce. Dokumenty 1948-1975, II:142-44. Skopje: Archiv na Makedonia.

---, ed. 2008b. "Świadectwo Ukończenia Macedońskiego Kursu Nauczycielskiego w Polsce, 15.09.1949 r." In Macedońscy Uchodźcy w Polsce. Dokumenty 1948-1975, I: 152-54. Skopje: Archiv na Makedonia.

Słabig, Arkadiusz. 2008. Aparat Bezpieczeństwa Wobec Mniejszości Narodowych Na Pomorzu Zachodnim w Latach 1945-1989. Szczecin: Instytut Pamięci Narodowej - Komisja Ścigania Zbrodni przeciwko Narodowi Polskiemu.

Wojecki, Mieczysław. 1989. Uchodźcy polityczni z Grecji w Polsce 1948-1975. Jelenia Góra: Urząd Wojewódzki. 